\title{
PENERAPAN TEKNOLOGI PANEL SURYA PADA BAGAN TANCAP UNTUK PENINGKATAN TANGKAPAN IKAN DITELUK JOR, KABUPATEN LOMBOK TIMUR
}

\author{
Application of Solar Panel Technology to Tancap Chart to Improve Fish \\ Catching in Jor Bay, East Lombok District
}

\author{
Dewi Putri Lestari ${ }^{1 *}$, Alfian Pujian Hadi ${ }^{2}$, Firman Ali Rahman ${ }^{3}$ \\ ${ }^{1}$ Program Studi Budidaya Perairan Universitas Mataram, ${ }^{2 *}$ Program Studi Pendidikan \\ Geografi Universitas Muhammadiyah Mataram, ${ }^{3}$ Program Studi Pendidikan Biologi \\ Universitas Nahdlatul Wathan
}

Jalan Pendidikan Nomor 37, Kota Mataram, Provinsi NTB

*Alamat Korespondensi: alfianpujianhadi@gmail.com

(Tanggal Submission: 3 April 2020, Tanggal Accepted: 30 Agustus 2020)

\begin{abstract}
ABSTRAK
Penggunaan energi listrik sebagai sumber pencahayaan pada bagan tancap sangat penting dalam penangkapan ikan. Pencahayaan berfungsi menarik ikan mencari sumber makanan di sekitar bagan. Pencahayaan/atraktor cahaya pada bagan bertujuan mengumpulkan ikan karena memiliki sifat fototaksis positif. Ikan yang bersifat fototaksis positif akan berkumpul di daerah cahaya lampu, sehingga memudahkan nelayan untuk menangkap ikan. Permasalahan yang dihadapi oleh nelayan saat ini adalah ketersediaan listrik. Salah satu alternatif penyelesaian permasalahan tersebut berupa penyediaan panel surya pada bagan tancap untuk memenuhi kebutuhan listrik dan menyimpannya dalam baterai Aki. Kegiatan pengabdian ini bertujuan untuk mendemontrasi teknologi panel surya pada bagan tancap sebagai penyedia sumber listrik untuk sumber pencahayaan dalam menangkap ikan, meningkatan pengetahuan melalui pelatihan penggunaan teknologi panel surya, serta menyusun strategi keberlanjutan kegiatan melalui optimalisasi peran lembaga LPATJ serta kerjasama dengan parapihak di Kawasan Teluk Jor, Kecamatan Jerowaru, Kabupaten Lombok Timur. Metode kegiatan yang dilakukan berupa demontrasi melalui pembuatan bagan tancap dengan melakukan instalasi panel surya serta pemasangan aki sebagai alat penyimpan arus listrik. Arus listrik yang tersimpan dalam aki kemudian akan digunakan pada malam hari oleh nelayan pada bagan masing-masing. Hasil kegiatan ini adalah pembangunan bagan tancap beserta demonstrasi peralatan teknologi panel surya dan peralatan pendukung lainnya telah dilakukan, dipahami operasionalisasinya serta digunakan secara langsung oleh kelompok. Pelatihan penggunaan Teknologi Panel Surya dapat menambah pengetahuan dan wawasan terutama pemanenan energi surya menjadi listrik serta penyimpanan listrik pada aki yang akan digunakan oleh nelayan pada malam harinya untuk menangkap ikan. Strategi Keberlanjutan melalui adanya inisiatif LPATJ untuk dapat melakukan kerjasama dengan para pihak untuk semakin mengembangkan penangkapan ikan dengan teknologi ramah lingkungan.
\end{abstract}

Kata kunci : Teknologi Panel Surya, Bagan Tancap, Tangkapan Ikan, Fototaksis Positif. 


\section{PENDAHULUAN}

Kawasan Teluk Jor, Kecamatan Jerowaru, Kabupaten Lombok Timur merupakan salah satu sentral penghasil komoditas perikanan baik perikanan tangkap maupun perikanan budidaya. Perikanan tangkap yang dikembangkan oleh nelayan berupa penangkapan ikan dengan perahu ketingting maupun perahu modern. Selain itu juga dikembangkan penangkapan ikan dengan teknik bagan tancap yang dilakukan oleh nelayan tradisional dengan teknologi yang sangat sederhana. Selain perikanan tangkap, tentunya terdapat juga perikanan budidaya. Teluk Jor terkenal sebagai kawasan penghasil lobster, bawal dan bandeng yang dipasarkan untuk memenuhi kebutuhan masyarakat di Pulau Lombok.

Teknik penangkapan ikan yang banyak digunakan oleh nelayan yakni teknik menggunakan bagan. Bagan merupakan salah satu alat tangkap yang digunakan untuk menangkap ikan dengan atraktor cahaya. Atraktor cahaya yang digunakan pada bagan bertujuan untuk mengumpulkan ikan yang mempunyai sifat fototaksis positif. Ikan yang bersifat fototaksis positif akan berkumpul di daerah cahaya lampu, sehingga memudahkan nelayan untuk menangkap ikan (Hasan, 2008).

Salah satu yang menjadi perhatian serius terhadap perikanan tangkap terutama bagi nelayan yang menggantungkan hidupnya mencari ikan dengan bagan tancap yaitu ketersediaan penerangan/pencahayaan pada malam hari untuk menarik ikan di sekitar bagan. Ketergantungan yang tinggi terhadap ketersediaan energi listrik dirasakan oleh masyarakat yang berprofesi sebagai nelayan di Kawasan Teluk Jor. Energi listrik menjadi sangat penting karena digunakan untuk penyinaran penangkapan ikan di bagan tancap oleh nelayan.

Alat tangkap bagan tancap termasuk salah satu alat yang menggunakan lampu listrik, kebanyakan masih menggunakan lampu boohlam yang dinyalakan dengan genset sebagai sumber penerang di alat bagan tancap. Untuk membantu perkembangan teknologi yang dimiliki oleh nelayan, Perguruan Tinggi perlu berperan serta dalam suatu penelitian terkait dengan permasalahan ini. Salah satu alternatif yang akan ditawarkan melalui penelitian ini adalah mengembangkan lampu LED (Light Emitting Diode) sebagai pengganti lampu bohlam dalam perikanan lampu (light fishing) listrik.

Permasalahan listrik memang menjadi kendala utama dalam penangkapan ikan di bagan tancap karena tanpa adanya pencahayaan/penerangan maka nelayan mengalami kesulitan menangkap ikan. Adanya lampu penerangan digunakan oleh nelayan untuk daya tarik berkumpulnya ikan. Selama ini, untuk sumber listrik, nelayan pemilik bagan tancap dan bagan apung menggunakan aki dan di cas di rumah masing-masing. Selain itu bagan tancap dan bagan apung yang lokasinya berdekatan dengan pemukiman dapat mengalirkan listrik PLN dari rumah masing-masing nelayan ke bagan tancapnya melalui jaringan kabel namun nampaknya ini beresiko tinggi karena jaringan listrik tersebut dapat menyebabkan terjadinya korban jiwa apabila kabelnya terputus. Berdasarkan hal tersebut diatas, maka beberapa tujuan dalam kegiatan pengabdian ini yaitu :

Demontrasi teknologi panel surya pada bagan tancap sebagai penyedia sumber listrik untuk memenuhi kebutuhan nelayan dalam menangkap ikan. Peningkatan pengetahuan melalui pelatihan penggunaan teknologi panel surya kepada kelompok LPATJ. Menyusun strategi keberlanjutan kegiatan melalui optimalisasi peran lembaga LPATJ serta kerjasama dengan parapihak.

\section{METODE PELAKSANAAN}

Alat dan Bahan

Alat yang digunakan dalam kegiatan ini berupa :

1. Panel surya dengan jumlah 10 unit

2. Aki beserta perangkat pengisiannya sejumlah 10 unit 
3. Seperangkat konektor berupa kabel, cok dan perangkat listrik lainnya.

Bahan yang digunakan yaitu bambu untuk pembuatan bagan tancap, tali plastik, seng, paku, dan lainnya.

\section{Lokasi kegiatan}

Kegiatan dilaksanakan di Dusun Telongelong, Kawasan Teluk Jor, Kecamatan Jerowaru, Kabupaten Lombok Timur. Adapun peta lokasi disajikan sebagai berikut (Gambar 1).

\section{Tahapan Kegiatan}

Kegiatan penerapan teknologi panel surya untuk peningkatan tangkapan ikan pada bagan tancap di Teluk Jor, Kabupaten Lombok Timur dilakukan menggunakan dua tiga sebagai berikut :

1. Tahap pertama berupa demonstrasi pembuatan bagan tancap terintegrasi panel surya. Kegiatan ini berupa pembuatan langsung agan tancap di lokasi yang telah disetujui oleh kelompok LPATJ. Bagan tancap yang dibuat disertai dengan instalasi panel surya yang terhubung dengan jaringan untuk penyimpan arus listrik (aki). Jumlah panel surya yang terpasang sebanyak 10 unit.

2. Tahap kedua berupa pelatihan. Pelatihan dilakukan kepada nelayan baik anggota LPATJ maupun nelayan lainnya di sekitar bagan tancap. Tujuan pelatihan yaitu memberikan pengetahuan kepada nelayan menyangkut operasional pemanfaatan panel surya beserta peralatan lainnya dalam pengisian aki.

3. Tahap ketiga berupa FGD perumusan strategi keberlanjutan kegiatan yang meliputi strategi pemeliharaan dan kerjasama para pihak.
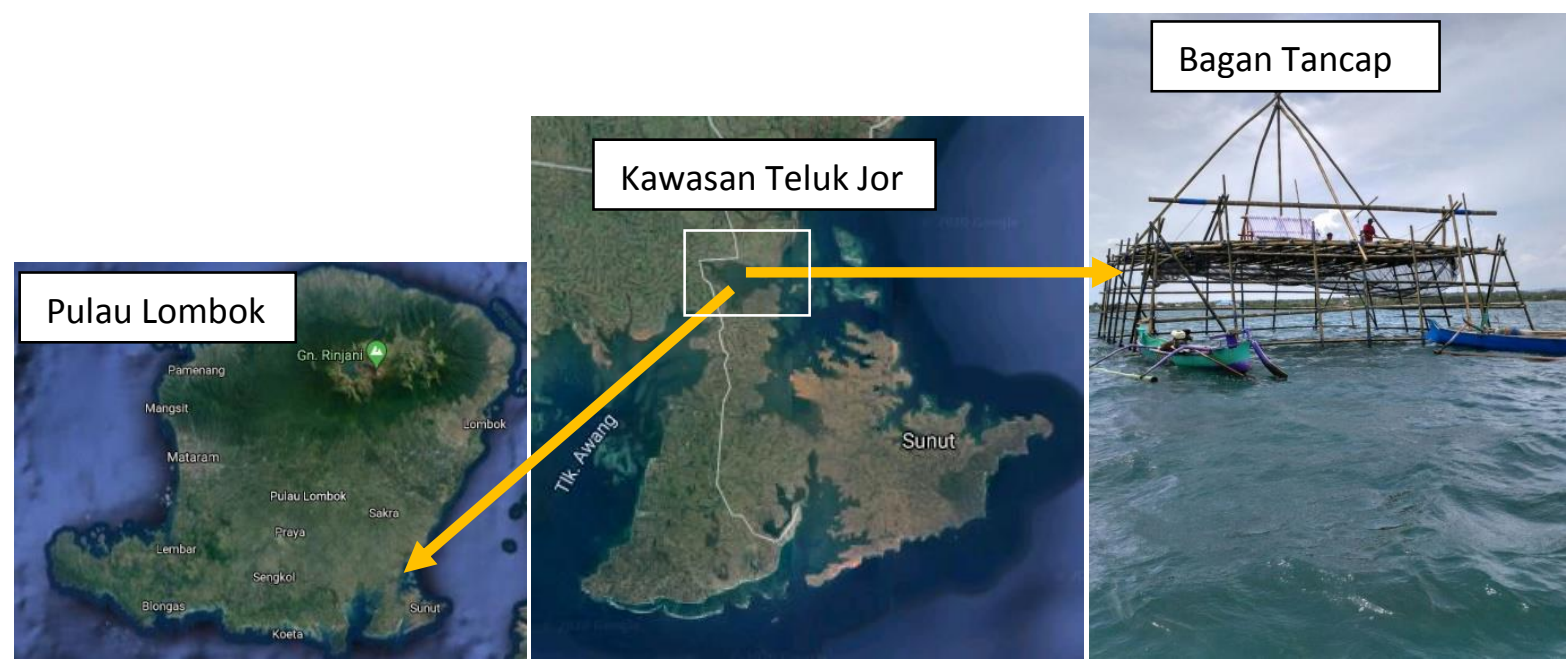

Gambar 1. Lokasi Kegiatandi Kawasan Teluk Jor, Kabupaten Lombok Timur

\section{HASIL DAN PEMBAHASAN}

Kegiatan penerapan teknologi panel surya pada bagan tancap untuk peningkatan tangkapan ikan di Teluk Jor, Kabupaten Lombok Timur dilaksanakan selama 3 bulan. Kegiatan ini dikerjakan oleh Lembaga Penegak Awiq-Awiq Teluk Jor (LPATJ) yang difasilitasi pendanaan maupun bimbingan teknis dari Blue Carbon Consorsium melalui dukungan Millenium Challange Account (MCA)
Indonesia. Kegiatan ini merupakan salah satu bentuk pemanfaatan teknologi ramah lingkungan rendah emisi untuk sektor perikanan. Manfaat yang diterima dalam kegiatan ini yaitu pengisian aki yang sedianya dilakukan nelayan di rumah akan lebih dekat dengan ketersediaan terminal bagan tancap panel surya untuk pengecasan baterai aki. 


\section{a. Demonstrasi Teknologi Panel Surya pada} Bagan Tancap

Pemanfaatan energi surya pada setiap waktu semakin meningkat seiring dengan pengetahuan yang kita dapatkan. Salah satu pemanfaatan energi surya adalah Pembangkit Listrik Tenaga Surya (PLTS) yang memanfaatkan energi foton cahaya matahari menjadi energi listrik. Indonesia sendiri, sebuah negara yang dilewati oleh garis khatulistiwa dan menerima panas matahari yang lebih banyak daripada negara lain, mempunyai potensi yang sangat besar untuk mengembangkan pembangkit listrik tenaga surya sebagai alternatif batubara dan diesel sebagai pengganti bahan bakar fosil, yang bersih, tidak berpolusi, aman dan persediaannya tidak terbatas (Rotib, 2001).

Metode penangkapan ikan yang menggunakan alat bantu cahaya atau yang dikenal dengan sebutan light fishing sudah dipakai sejak awal tahun 1900-an di Norwegia, Jepang dan Cina. Sementara, nelayan Indonesia baru mengenal teknik ini sekitar tahun 1950-an. Teknik ini pertama kali digunakan oleh nelayan di perairan Sulawesi Selatan dengan menggunakan lampu petromaks pada alat tangkap bagan tancap. Bagan tancap merupakan kelompok jaring angkat (lift net) yang dipasang menetap di perairan dengan menggunakan rangka dari bambu. Lampu LED bisa digunakan dalam perikanan bagan tangkap. Hasilnya, bisa menghemat bahan bakar sekaligus bisa meningkatkan kualitas tangkapan. Nelayan di Indonesia menangkap ikan dengan berbagai jenis alat tangkap, antara lain pancing, jaring, bubu, jala serta penggunaan teknologi penangkapan ikan dengan alat bantu cahaya.

Sebelum dilakukan demonstrasi teknologi panel surya kepada masyarakat, kegiatan diawali dengan pembuatan bagan tancap. Hal ini guna membantu masyarakat nelayan yang memiliki bagan tancap menyediakan energi listrik dengan teknologi panel surya di kawasan Teluk Jor Kabupaten Lombok Timur. Kegiatan pembangunan bagan tancap dilakukan bekerjasama dengan Lembaga Penegak
Awiq-Awiq Teluk Jor (LPATJ) serta pemerintah daerah memiliki komitmen yang sama untuk membantu masyarakat nelayan melalui konsep pembangunan pesisir rendah emisi.

Pengelolaan bagan tancap dengan pembangkit listrik tenaga surya dioperasikan oleh LPATJ sekaligus sebagai penanggung jawab kegiatan di lapangan dengan peran utama memastikan operasionalisasi bagan tancap untuk penangkapan ikan dan penggunaan panel surya untuk nelayan. Selain itu juga berperan dalam menjaga dan memelihara instalasi panel surya agar dapat terus digunakan oleh nelayan di Teluk Jor.

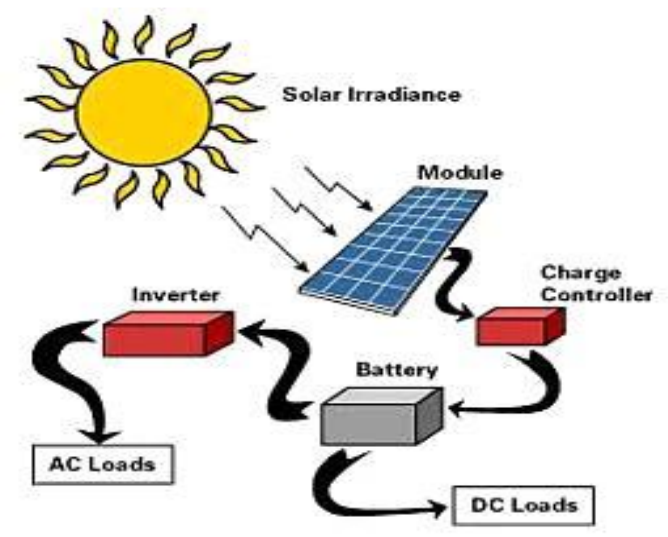

Gambar 2. Sistem Alur pemasangan Jaringan Panel Surya (Bekak, 2017)

Untuk lampu penerangan dipasang lampu LED merupakan lampu terbaru yang merupakan sumber cahaya yang efisien energinya. Sebuah LED adalah sejenis dioda semikonduktor istimewa. Seperti sebuah dioda normal, LED terdiri dari sebuah chip bahan semikonduktor yang diisi penuh, atau didop, dengan ketidakmurnian untuk menciptakan sebuah struktur yang disebut $p-n$ junction. Pembawa muatan-elektron dan lubang mengalir ke junction dari elektroda dengan voltase berbeda. Ketika elektron bertemu dengan lubang, dia jatuh ke tingkat energi yang lebih rendah, dan melepas energi dalam bentuk photon (Routledge, 2002).

Cahaya digunakan untuk menarik perhatian ikan yang menyukai cahaya (fototaksis positif) agar berkumpul di sekitar area penangkapan.Sumber cahaya yang digunakan nelayan biasanya berasal 
dari lampu. Teknologi yang digunakan oleh nelayan berevolusi dari tahun ke tahun. Diawali dari pemakaian obor lalu beralih hingga yang terakhir penggunaan lampu neon dan lampu hemat energi LED (light emitting diode). Target utama penangkapan ikan menggunakan bagan tancap adalah berbagai jenis ikan teri (Stolephorus sp.), cumi-cumi (Loligo sp.) dan ikan pelagis lainnya. Berkembangnya teknologi LED sebagai generasi terbaru lampu hemat energi membawa dampak positif bagi penghematan konsumsi energi di seluruh dunia.

Lampu LED digunakan dalam kegiatan ini karena lampu tersebut tersedia banyak dipasaran. Hal ini berdasarkan informasi dari berbagai pihak bahwa lampu LED dapat memikat ikan cepat. Namun hal ini juga dilakukan dengan serangkaian proses penelitian dan uji coba agar bisa sesuai dengan kebutuhan nelayan. Misalnya, penelitian harus memperhatikan jenis alat tangkap dan target ikan tangkapan. Sumber energi lampu LED selain dari generator listrik juga dapat menggunakan energi lainnya yang lebih ramah lingkungan. Sumber energi terbarukan lain yang dapat digunakan sebagai sumber energi listrik untuk menyalakan lampu LED antara lain sinar matahari melalui pemanfaatan panel surya, pembangkit listrik tenaga angin maupun pembangkit listrik tenaga air laut. Kombinasi pemanfaatan sumber energi terbarukan sebagai sumber listrik akan meningkatkan efisiensi usaha perikanan di masa mendatang. Aplikasi lampu LED juga dapat dikombinasikan dengan sistem kendali mikro, sehingga warna dan intensitas yang diinginkan dapat diatur sesuai dengan target tangkapan yang diinginkan.

Kombinasi teknologi LED, kendali mikro dan sumber energi terbarukan diharapkan mampu menghasilkan teknologi lampu pintar (smart fishing lamp) sehingga dapat menghasilkan lampu yang ideal untuk perikanan bagan. Hal ini penting dilakukan mengingat konsep pengembangan

\footnotetext{
${ }^{1}$ Adi Susanto, "Riset: Penggunaan Teknologi Lampu Hemat Energi LED Dalam Penangkapan Ikan Lebih
}

teknologi ini juga belum dilakukan di luar negeri pada perikanan tangkap skala kecil1.

Secara umum, respons ikan terhadap sumber cahaya dapat dibedakan menjadi dua kelompok, yaitu bersifat phototaxis positif (ikan yang mendekati datangnya arah sumber cahaya) dan bersifat phototaxis negatif (ikan yang menjauhi datangnya arah sumber cahaya) (Subani,1972). Ikanikan yang bersifat phototaxis positif secara berkelompok akan bereaksi terhadap datangnya cahaya dan berkumpul di sekitar cahaya pada jarak dan rentang waktu tertentu. Selain menghindari serangan predator (pemangsa), juga untuk kegiatan mencari makan.

Menurut He (1989) dalam Wagio (2003), terdapat teori tentang ikan berenang mendekati sumber cahaya (fototaksis) yaitu faktor internal seperti umur, jenis kelamin dan kepenuhan isi lambung serta faktor eksternal seperti temperatur air, level lingkungan cahaya, intensitas dan warna dari sumber cahaya, ada tidaknya makanan dan kehadiran predator.

Menurut Derec (2009) mengemukakan perbedaan warna cahaya lampu yang digunakan nelayan dalam penangkapan ikan akan memberikan hasil yang berbeda pada jumlah tangkapan, perbedaan ini akibat dari jenis ikan tersebut senang atau tertarik pada warna dan intensitas sinar tertentu.

Dalam demonstrasi ini juga dipraktekkan bagaimana cara melakukan pengecasan aki untuk penyimpanan listrik. Batterai atau accu berfungsi untuk menyimpan arus/energi listrik yang dihasilkan panel surya. Kegunaan baterai dalam sistem Pembangkit Listrik Tenaga Surya (PLTS) sangat berguna untuk menyimpan arus/energi listrik yang dihasilkan dari solar cell/panel pada waktu siang hari dan dapat digunakan ke beban yang dibutuhkan pada malam hari maupun siang (Bekak, 2017).

Menguntungkan," The Conversation, accessed March 28, 2020, http://theconversation.com 


\section{b. Pelatihan penggunaan Teknologi Panel Surya} kepada kelompok LPATJ

Pelatihan penggunaan teknologi panel surya kepada kelompok LPATJ dilakukan untuk meningkatkan pengetahuan baik teoritis maupun teknis dalam mengoperasionalisasikan peralatan yang terpasang di bagan tancap. Dengan pelatihan ini maka setiap anggota kelompok akan mampu
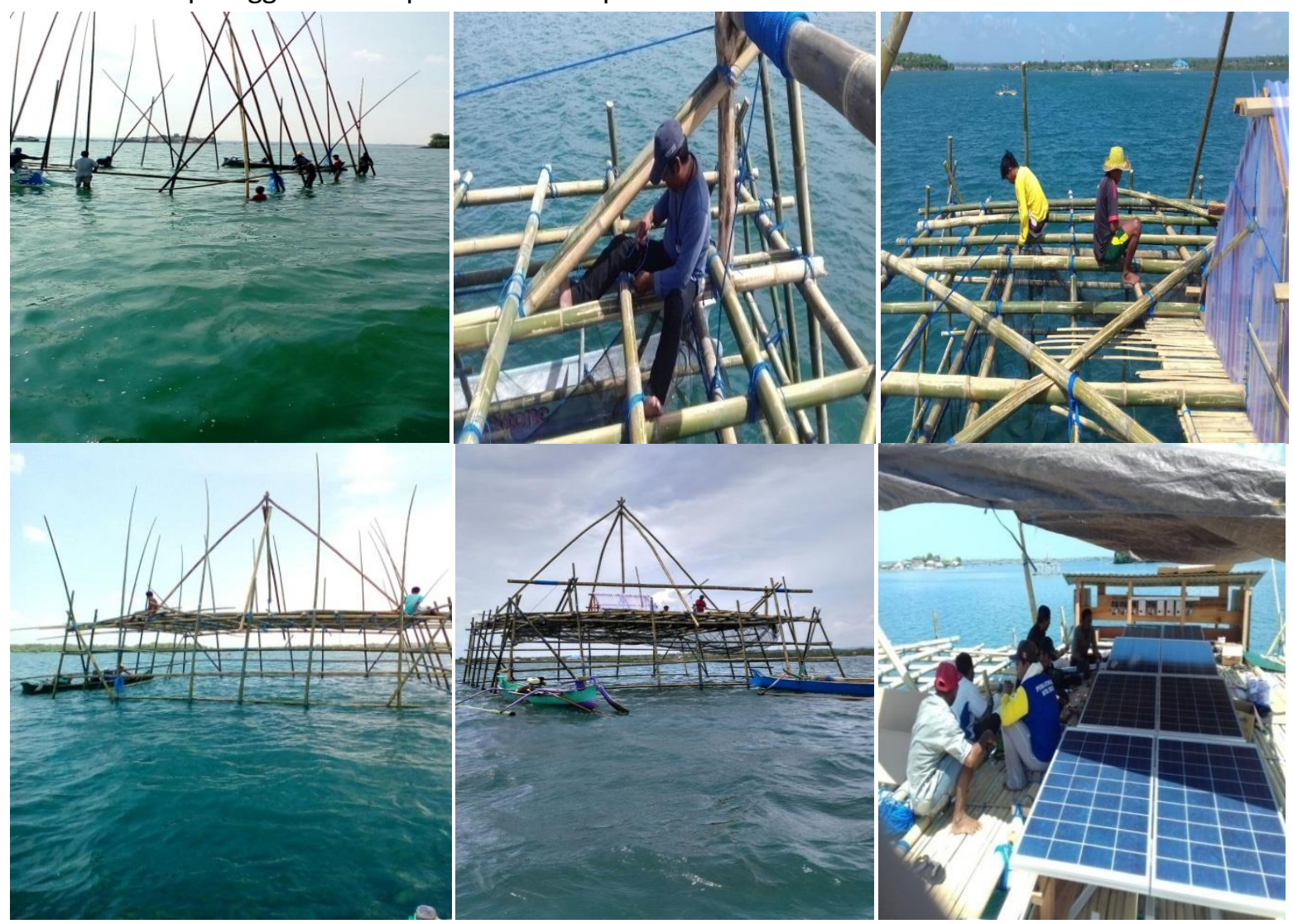

Gambar 3. Demonstrasi Bagan Tancap dengan Teknologi Panel Surya

Jumlah nelayan yang memiliki bagan tancap di sekitar lokasi cukup banyak sekitar 50 orang. Dengan kapasitas pengecasan yang hanya 10 maka tentunya alat ngecas yang dimiliki oleh kelompok LPATJ masih kurang dan belum dapat mencukupi kebutuhan nelayan setempat yang memiliki bagan tancap. Keterbatasan lainnya juga yaitu proses pengecasan yang cukup lama sekitar 8 jam sehingga nelayan lainnya yang tidak mendapatkan kesempatan ngecas aki akhirnya mengisi aki di rumah masing-masing.

Namun demikian, dengan adanya pelatihan ini paling tidak upaya menuju melakukan pengisian aki sendiri dengan melakukan alat pengecasan ke aki dari sumber listrik (panel surya). Pelatihan dilakukan kepada anggota kelompok sebanyak 20 orang anggota dan nelayan sekitar. 
anggota LPATJ yang hadir sebagai peserta pelatihan.

Dalam pelatihan ini dilakukan sharing pengetahuan tentang konstruksi unit penangkapan bagan perahu terdiri atas kerangka kayu, waring/jaring serta perahu bermotor yang sekaligus sebagai alat transportasi di laut. Jenis lampu yang digunakan oleh bagan sebagai atraktor untuk memikat ikan, yaitu lampu petromaks, lampu neon, dan lampu merkuri. Cahaya lampu pada bagan, berfungsi untuk menarik ikan agar berkumpul di sekitar perahu kemudian dilakukan penangkapan dengan menggunakan jaring (Aswar, 2018)
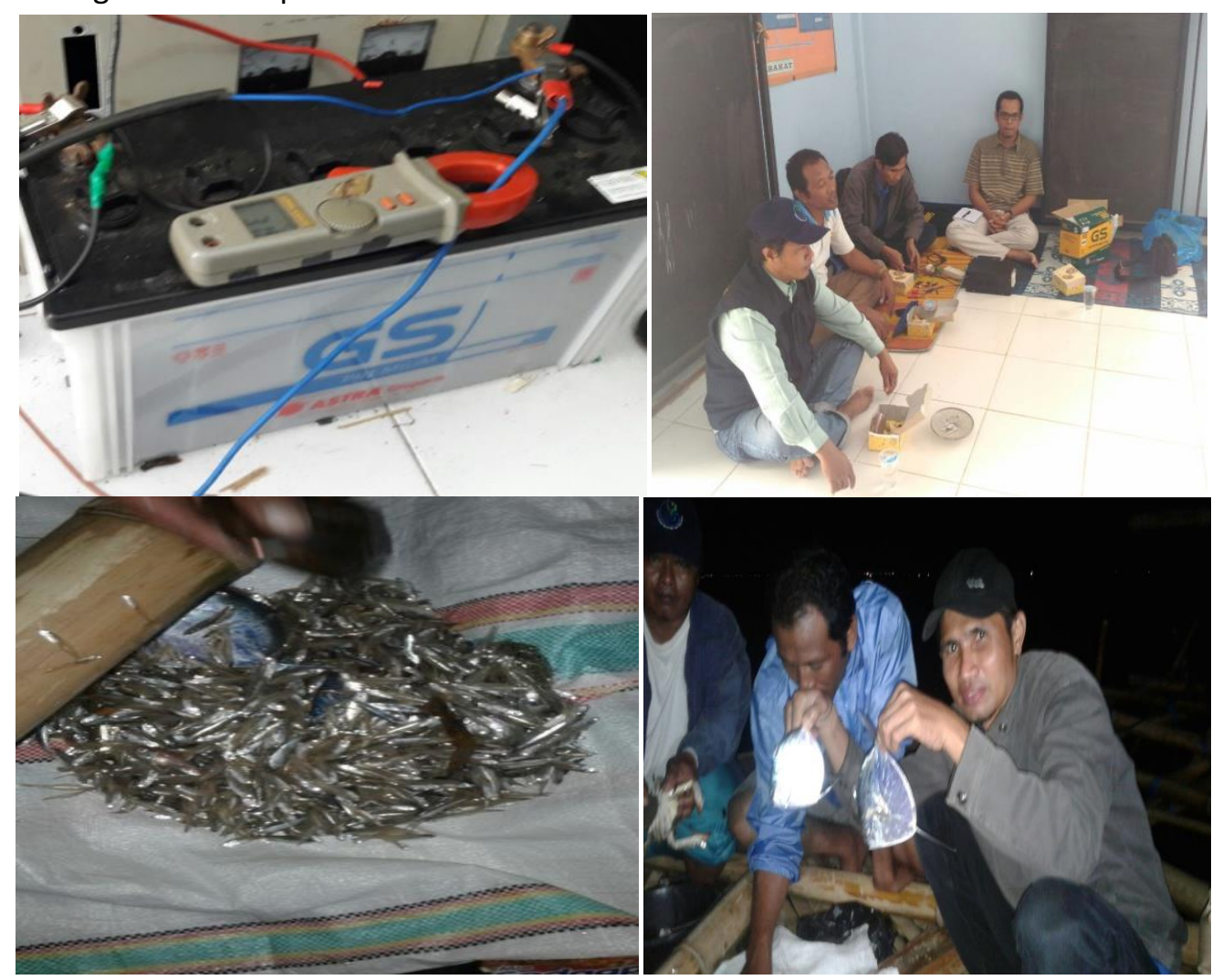

Gambar 4. Pemasangan Aki, Simulasi sekaligus Pelatihan Penangkapan Ikan dengan Aki yang telah diisi dengan listrik yang bersumber dari panel surya

Pada saat simulasi sekaligus pelatihan operasional dimana pemanfaatan sumber listrik dengan lampu LED menggunakan aki kering berdaya DC. Pengisian aki kering dilakukan oleh solar cell yang dipasang pada alat bagan tancap. Hasil yang didapatkan berupa ikan teri.

Salah satu cara yang bisa dilakukan adalah penggunaan cahaya sebagai alat bantu untuk memancing ikan berkumpul di area penangkapan (catchable area) lalu kemudian menangkapnya. Ikan laut memiliki sensitifitas yang tinggi terhadap cahaya (Sudirman dan Mallawa, 2004). Tingkah laku ikan kaitannya dalam merespon sumber cahaya yang sering dimanfaatkan oleh nelayan adalah kecenderungan ikan untuk berkumpul di sekitar sumber cahaya (Wiyono, 2006)

\section{c. Strategi Keberlanjutan Kegiatan}

Strategi keberlanjutan merupakan upaya yang dilakukan dalam rangka menjaga kegiatan yang telah dibangun agar dapat terus berlanjut tanpa adanya dukungan pihak lain. Strategi yang dilakukan berupa mengoptimalkan peran kelembagaan kelompok LPATJ yang ada di Teluk Jor untuk dapat mengelola bagan tancap yang 
telah dibuat untuk kepentingan seluruh anggotanya. Dengan mengoptimalkan peran kelembagaan LPATJ tersebut maka akan berimplikasi pada beberapa hal diantaranya, a) adanya perhatian kelompok dalam menjaga operasionalisasi bagan, b) kebutuhan operasionalisasi dapat ditangani secara mandiri termasuk apabila terjadi kerusakan bagan. Hal ini penting karena bagan umumnya dapat bertahan selama 2-3 tahun an setelah itu perlu perbaikan karena material bambu yang mudah lapuk. Kebutuhan perbaikan baik material bambu maupun kerusakan pada perangkat panel surya dan aki diharapkan dapat dilakukan melalui dana yang terkumpul di Lembaga LPATJ. c) LPATJ dapat melakukan kerjasama dengan para pihak untuk semakin mengembangkan penangkapan ikan dengan teknologi ramah lingkungan.

Dalam menjaga keberlanjutan operasionalisasi tersebut maka skema yang dikembangkan oleh kelompok berupa kesepakatan bersama diantaranya hasil penangkapan ikan di bagan tancap dan operasionalisasi panel surya akan dibagi berdasarkan proporsi $50 \%$ untuk operasional pengelola bagan, $25 \%$ untuk penguatan kapasitas, kelembagaan serta aktivitas LPATJ serta $25 \%$ untuk biaya pemeliharaan bagan tancap.

\section{KESIMPULAN}

Beberapa hal yang dapat disimpulkan berdasarkan hasil pelaksanaan kegiatan pengabdian kepada masyarakat ini adalah sebagai berikut :

Kegiatan pembangunan bagan tancap beserta demonstrasi peralatan teknologi panel surya dan peralatan pendukung lainnya telah dilakukan kepada anggota Lembaga LPATJ dan nelayan lainnya. Demonstrasi penggunaan bagan tancap ini sudah dipahami operasionalisasinya oleh anggota kelompok dan dapat digunakan melalui bimbingan
Pelatihan penggunaan Teknologi Panel Surya kepada kelompok LPATJ dapat menambah pengetahuan dan wawasan anggota LPATJ. Pengetahuan yang diperoleh tersebut akan berguna dalam operasionalisasi bagan tancap terutama pemanenan energi surya menjadi listrik serta penyimpanan listrik pada aki yang akan digunakan oleh nelayan pada malam harinya untuk menangkap ikan.

Strategi Keberlanjutan yang dilakukan dengan mengoptimalkan peran parapihak terutama LPATJ melalui adanya inisiatif LPATJ untuk dapat melakukan kerjasama dengan para pihak untuk semakin mengembangkan penangkapan ikan dengan teknologi ramah lingkungan.

\section{UCAPAN TERIMA KASIH}

Ucapan terima kasih yang sebesarbesarnya penulis sampaikan kepada Dinas Perikanan dan Kelautan Kabupaten Lombok Timur, Proyek Millenium Challange Account (MCA) Indonesia yang telah mendanai kegiatan ini. Terima kasih pula kepada Lembaga Penegak AwiqAwiq Teluk Jor (LPATJ) yang telah bekerjasama dengan sangat baik untuk mensukseskan kegiatan ini sehingga program pemberdayaan masyarakat ini dapat dimanfaatkan untuk peningkatan kesejahteraan masyarakat pesisir khusunya di Kawasan Teluk Jor, Dusun Telong-elong, Desa Jerowaru, Kecamatan Jerowaru, Kabupaten Lombok Timur.

\section{DAFTAR PUSTAKA}

Aswar, MBA. 2018. Perancangan sistem pembangkit listrik hybrid panel surya (photovoltaic) dan generator Pada floating platform. (Skripsi) Departemen teknik sistem perkapalan Fakultas teknik Universitas Hasanuddin. Makasar.

Bekak, DO., Letik.,MD.2017. Desain Penerangan Bagan Tancap/Tanam Bagi 
Nelayan Tradisional Di Lasiana Dan

Tuak Sabu Dengan Menggunakan Pembangkit Listrik Tenaga Surya (PLTS). Jurnal IImiah FLASH Volume 3 Nomor 1.

Derec, M.N. 2009. Preferensi Larva Cumi-Cumi Sirip Besar terhadap Perbedaan Warna dan Tingkat Intensitas Cahaya pada Waktu Pengamatan yang Berbeda. (Skripsi) Departemen Pemanfaatan Sumberdaya Perikanan Fakultas Perikanan Dan Ilmu Kelautan Institut Pertanian Bogor Bogor.

Hasan. 2008. Uji Coba Penggunaan Lampu Lacuba Tenaga Surya padABagan Apung terhadap hasil tangkapan Ikan di Pelabuhan ratu, Jawa Barat, Jurnal Sains dan Teknologi Indonesia. 2(3):1118

Rotib, W. 2001. Aplikasi Sel Surya Sebagai Sumber Energi Alternatif; Dimensi Vol 4 No. 1 Juni 2001. www.istecs.org.

Routledge, G. 2002. Lighting The Way To A LowEnergy Future. IEE Review Volume 48.

Subani W, Barus HR. 1972. Alat Penangkapan Ikan dan Udang di Indonesia. Nomor 59 Tahun 1988/199. Edisi Khusus. Jurnal Penelitian Perikanan Laut. Jakarta :
Balai Penelitian Perikanan Laut, Badan Penelitian Perikanan Laut, Departemen Pertanian. 245 hal

Sudirman H, A Mallawa. 2004. Teknik Penangkapan Ikan. Jakarta. Rineka cipta.

Sukardi, Subari Yanto, Kadirman. 2017. Pengaruh warna cahaya lampu dan intensitas cahaya yang berbeda terhadap espons benih ikan bandeng chanos - chanos forskal) dan benih ikan nila (oreochromis niloticus). Jurnal Pendidikan Teknologi Pertanian, Vol. 3.

Susanto, Adi. 2010. Penggunaan Teknologi Lampu Hemat Energi LED Dalam Penangkapan Ikan Lebih Menguntungkan. http://theconversation.com

Wagio, D. 2003. Pola Reaksi dan Adaptasi Ikan Selar (Selaroides leptolepis) dan Pepetek (Secutor indicius) Terhadap cahaya Warna Putih, Merah dan Biru (Skripsi) Program Pasca Sarjana Institut Pertanian Bogor.

Wiyono, S. 2006. Menangkap Ikan Menggunakan Cahaya. Artikel IPTEKBidang Biologi, Pangan dan Kesehatan. 